\title{
Shore-based observations of seasonality, movements, and group behavior of southern right whales in a nonnursery area on the South African west coast
}

\author{
Jaco Barendse, ${ }^{1}$ Mammal Research Institute, University of Pretoria, c Iziko South \\ African Museum, PO Box 61, Cape Town, 8000, South Africa and Sustainability Research \\ Unit/South African National Parks, Nelson Mandela Metropolitan University, Private Bag \\ X6531, George, 6530, South Africa; Peter B. BeSt, Mammal Research Institute, \\ University of Pre-toria, \% Iziko South African Museum, PO Box 61, Cape Town, 8000, \\ South Africa.
}

${ }^{1}$ Corresponding author (e-mail: jaco.barendse@gmail.com).

\begin{abstract}
The southern right whale's (Eubalaena australis) demography, occurrence, habitat use, and behavior off South Africa are known predominantly from an ongoing aerial survey data set that started in 1971. The fixed timeframes of these surveys and their geographical bias towards south coast nursery areas have constrained our knowledge about the right whale's seasonal distribution elsewhere. We present shore-based observations and tracking of right whales at Saldanha Bay on the west coast (2001-2003) that reveal a near year-round presence and strongly nearshore distribution. With seasonal progression from winter to summer we observed a gradual increase in sighting rate, reduction in swimming speed, less directionality of movement, an increase in group size, and more surface active groups. The area appears to be impor-tant for feeding and socializing but not as a calving or nursery area. Individual tran-sits between the south and west coasts, bidirectional alongshore movements, and extended seasonal presence may all be indicative of reoccupation of their former range along the west coast. This is important given the increasing ship traffic at Saldanha Bay, the rapid expansion of the region's oil and gas industry, and the known vulnerability of the closely related North Atlantic right whale (E. glacialis) t o ship strikes.
\end{abstract}

Key words: southern right whale, shore-based observations, seasonality, distribu-tion, habitat use, feeding, theodolite tracking, Pythagoras, Southern Benguela upwelling, South Africa.

As the sole member of the genus Eubalaena found in the Southern Hemisphere, the southern right whale $E$. australis has a circumpolar distribution with calving grounds located in the coastal waters of Southern Africa, South America, Australia, New Zealand, and several other mid-latitude islands (Richards 2009). The species' historic exploitation followed a similar progression throughout its range, including the southwestern Cape of South Africa (Thompson 1913). The so-called "Cape of Good Hope" grounds that included Table, Saldanha, and St. Helena Bays (see Fig. 1a) showed particularly good potential for shore-based whaling, which became an 


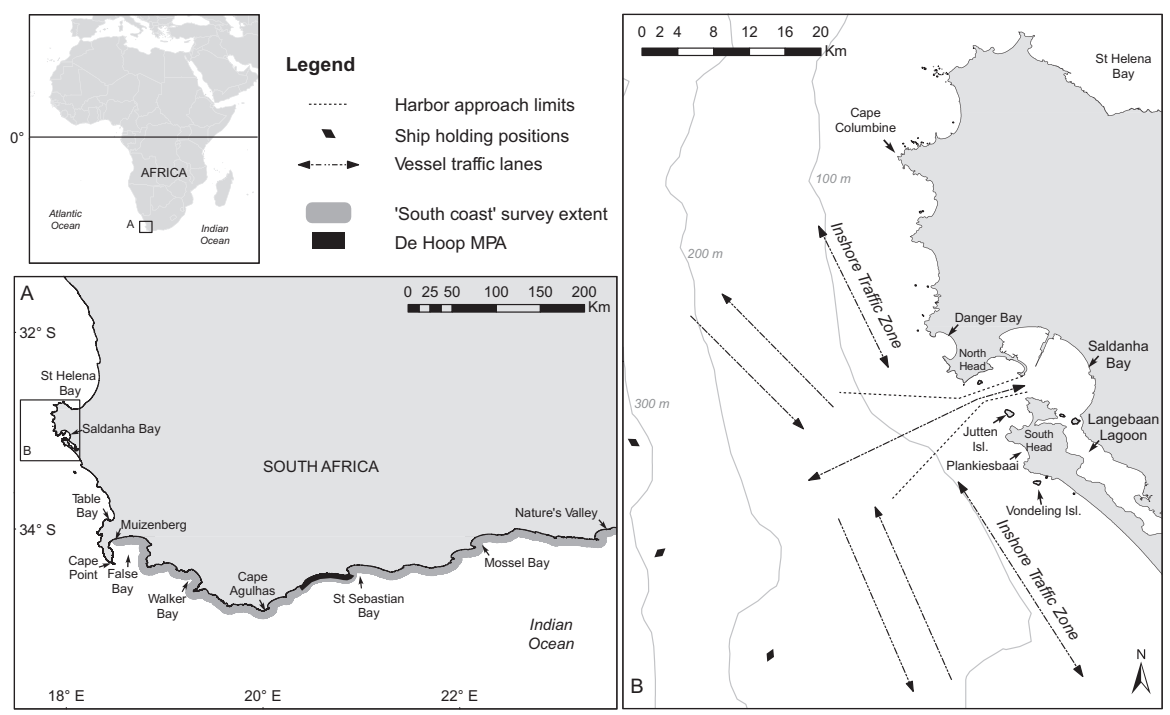

Figure 1. (a) The southwestern Cape coastline of South Africa, showing the area on the "south coast" between Muizenberg and Nature's Valley that is routinely surveyed for southern right whales, and other major features and areas of importance for the species, such as major bays and the De Hoop Marine Protected Area (MPA); and (b) detail of the greater Saldanha Bay study area, designated harbor approaches and shipping lanes from Chart ZA400040 of the South African Naval Hydrographic Office (SANHO), and other localities referred to in text.

established industry shortly before British colonial occupation in 1795 (Thompson 1913, Best 1970). But even before this time (between the years 1785 and 1792), French, British, and American whaling vessels (Richards and Du Pasquier 1989) had taken a minimum estimated total of 1,484 right whales in St. Helena Bay (Best 2006a). By the 1830s the "local populations" of right whales in these bays had been depleted, a situation that persisted until comparatively recently, despite putative full protection of the species since 1935 (Best 1970, Best and Ross 1986).

As a result of this depletion, aggravated by illegal Soviet catches in the Southeast Atlantic from 1951 to 1972 (Tormosov et al. 1998), it is not surprising that most research effort on southern right whale populations has focused on their recovery from whaling. This has been monitored in South Africa since 1971 by means of aerial surveys (Best 1990, 2000). These data have served to elucidate the population's demography (e.g., Best et al. 2001), describe their coastal distribution (Best 2000), group composition (Best et al. 2003), and environmental factors that may affect these (Elwen and Best 2004a, b). Sheltered bays on the south coast (particularly those at St. Sebastian Bay, De Hoop, and Walker Bay; Fig. 1a) are favored by (principally) right whale females for calving and nursing of newborn calves during winter (Elwen and Best 2004c), with the peak calving season occurring in August (Best 1994).

Due to the focus on the known nursery areas and breeding seasons, and logistical and funding constraints associated with aerial surveys, the area routinely covered is the coast between Muizenberg and Cape Agulhas (the southernmost point of Africa), and eastwards to Nature's Valley - from here on referred to as the south coast (see 
Elwen and Best 2004a and Fig. 1a). The timing of the surveys is limited to the months of September to early October and only on rare occasions does effort extend up the west coast or fall outside of these months (Best 2000). Shore-based observations from the west coast are limited to a single month's duration (October/November), collected as part of a pilot study directed at humpback whales Megaptera novaeangliae at Cape Columbine (Fig. 1b) (Best et al. 1995). Consequently, the distribution and seasonal occurrence of right whales off the west coast of South Africa have gone largely undescribed.

Here we present primarily shore-based observations on the seasonality, movements, and behavior of right whales made during a project that focused on humpback whales off Saldanha Bay, on the west coast (Barendse et al. 2010, 2011).

\section{Material ANd Methods}

\section{Study Area and Data Collection}

The study area and time period of data collection are identical to those described fully in Barendse et al. (2010) for humpback whales. In brief: a shore-based watch was kept on days with suitable sighting conditions from a lookout situated on the North Head of Saldanha Bay (Fig. 1b). This occurred during two periods of fieldwork: 24 July to 20 December 2001, and 6 May 2002 to 15 February 2003. Searching was conducted both by naked eye and binoculars by teams of $2-4$ observers. We attempted to track all groups of whales sighted using a Wild T1 manual theodolite (with $22 \times$ telescope), where a group was defined as one or more individuals estimated to be no farther than $100 \mathrm{~m}$ from each other, and showing similar movement patterns and/or behavior. At each surfacing event we established at least one theodolite "fix" and the following data were collected: (1) time, to the nearest second; (2) simultaneous vertical and horizontal angles (to the nearest second) measured by the theodolite; (3) behavioral cue (body, blow, breach, splash, or slick) fixed upon; and (4) best estimate of group size. We attempted throughout to obtain a fix on at least three separate surfacing events after the initial sighting, after which observers would continue to monitor the group's movements.

We calculated a relative sighting rate for both groups and individual whales seen from the shore (based on the best estimate of group size) and expressed it as "Sightings per Unit Effort" (SPUE): the number of groups/individuals seen per $10 \mathrm{~h}$ of searching. While every attempt was made to avoid duplicate recording of the same sighting on any one day, this cannot be excluded, either due to groups being "lost" by observers and resighted or by groups splitting or combining with others. Moreover, for the SPUE calculated for individual whales it should be noted that we have less confidence in size estimates for groups sighted with no reliable theodolite fix, i.e., they were difficult to track (see below). Therefore, the SPUE should be considered indicative of relative, rather than absolute abundance.

Weather permitting, a $6 \mathrm{~m}$ semi-rigid inflatable boat was directed by the shorebased personnel to all sightings reachable by a small vessel, within a radial distance of about $20 \mathrm{~km}$ from the mouth of Saldanha Bay. Whale groups spotted incidentally from the boat without assistance from land, e.g., during transit from the harbor into Saldanha Bay (especially in the areas not visible from the lookout) were also intercepted. Although priority was given to humpback whales, attempts were made to intercept all available whales. Right whale data collected and reported 
here are limited to GPS position, group size, composition, and selected behaviors (see below). Disturbance of whales was kept to the minimum during boat approaches.

\section{Trackline and Spatial Analysis}

The methodology followed is described in detail in Barendse et al. (2010). A trackline (or "track") was made up of three or more fixes taken during sequential surfacing events. If more than one fix was taken per surfacing event, one was selected giving priority to cues in the following order: body, splash, blow, slick, and breach. The software program Pythagoras (Gailey and Ortega-Ortiz 2000, 2002) was used to calculate the longitude and latitude from theodolite readings at each fix, with corrections for tidal fluctuations and refraction included. These coordinates (in decimal degrees) were imported into a Global Information System (GIS) (ArcMap 9.2 and Arcview 3.3 from ESRI, Redlands, CA) for spatial analysis and mapping, and the distances of whale groups (from the first fix of a track) to the nearest "smoothed" coastline (i.e., excluding major bays) were calculated for all groups with at least one reliable fix.

For each track with three or more reliable fixes at different surfacings, Pythagoras calculated the following parameters: (1) mean actual swimming speed or "leg" speed in $\mathrm{km} / \mathrm{h}$ (the unweighted mean of swimming speeds calculated for each leg); (2) net speed $(\mathrm{km} / \mathrm{h})$, the linear distance traveled between the first and last fixes of a track divided by the duration of the track; (3) linearity of movement, calculated by dividing the linear distance between the start and end of the track by the sum of the distance of each leg, and expressed as a decimal fraction between 0 and 1, where near-straight movement paths have values closer to 1; and (4) net course, the bearing between the first and last fixes of a track, in degrees true.

\section{Group Behavioral Observations}

No focal animal behavioral observations were made during sighting and tracking, but the general behavior attributed to the entire group was noted. Behavior was classified as one of six broad types: (1) "Passive," or nonenergetic behavior, such as logging and sailing; where a behavior was not specifically recorded it was assumed to have been passive and included here; (2) "Milling," or slow, nondirectional movement; (3) "SAGs," or surface active groups of two or more whales, usually associated with courting or mating (see description in Best et al. 2003); (4) "Other active" which included any activity other than SAGs, e.g., aerial or other high energy behavior such as breaching, tail or flipper slapping, or combinations of these by one or more animals; (5) "Possible feeding," or movements that suggested feeding such as frequent short dives, open mouth, etc.; and (6) "Traveling," or noticeably directional movement, sometimes associated with other behavior types. Except for traveling, in cases where both passive (including milling) and active behaviors were seen in the same group, the most active behavior was given priority.

In addition to observations from land, limited behavioral data were collected during boat intercepts, i.e., all encounters with cow-calf pairs (where calves were visually identified according to their length, relative to that of the cow), all occurrences of SAGs, and all instances of possible feeding behavior (see above) and actual defecations. 


\section{Seasonality}

Similar to Barendse et al. (2010) we pooled data (SPUE, group size, and movement parameters) collected in the same month in the two different periods of fieldwork into one seasonal subsample, from here on referred to as a "subseason." In addition, for the months with data available from only a single field season (i.e., May 2001, June 2001, January 2002) or where a month was only partially covered (July 2001, February 2003), some were combined into subseasons. This resulted in the following seven subseasons: autumn to mid-winter (May and June 2002, July 2001/2002), late winter (August 2001/2002), early spring (September 2001/2002), mid-spring (October 2001/2002), late spring (November 2001/2002), early summer (December 2001/2002), and mid- to late summer (January and February 2003).

\section{RESUlts}

\section{Search Effort and Sightings}

Shore-based searches took place on $282 \mathrm{~d}$ (1,802.18 h in total) during which 669 groups of southern right whales were sighted on 188 separate days. The search effort was highly variable, with less than $10 \mathrm{~h}$ in some weeks (Fig. 2) as a result of unfavorable sighting conditions, and no coverage in March and April (see Barendse et al. 2010 for a full discussion). Right whales were present in all but four weeks, in autumn, mid-winter, and late summer of the second data collection period (Fig. 2). During both collection periods, the sighting rates in all autumn and winter subseasons were lower than the average rate of 4.14 groups per $10 \mathrm{~h}$; this despite high and relatively consistent search effort; however, there were also inter-annual differences in the SPUE trends between 2001 and 2002/03 collection periods. There was a significant difference between the pooled subseasonal samples for group SPUE (Table 1; $n=57$, Kruskal Wallis ANOVA, $H=25.83, \mathrm{df}=6, P=0.001)$. The group SPUE for autumn to mid-winter was the lowest recorded and differed significantly from early spring $(Z=3.45, P<0.012)$, mid-spring $(Z=3.60, P<0.007)$, and early summer $(Z=4.26, P<0.004)$, as determined by Dunn's multiple comparison post hoc test. Both collection periods were characterized by fluctuating SPUE on a fortnightly basis. From about the last week of late winter, there was a steady increase in SPUE up to a peak in mid-spring (Fig. 2). The sighting rates then dropped, to rise again in the third week of late spring for the first collection period, and the first week of early summer during the second period. The highest overall SPUE for both groups and individuals was recorded during an extended period of about six weeks with generally high sighting rates, starting on 1 December 2002 (first week of early summer), and lasting until the second week of January 2003 (mid-summer). Early summer was also the subseason with highest mean group SPUE, at almost one group seen every hour (Table 1).

\section{Distance from Shore}

Of the 669 groups sighted we obtained one reliable fix from shore for 450 of these. This showed southern right whales to have a strongly nearshore distribution (Fig. 3). Groups sighted within $1 \mathrm{~km}$ from the coastline abutting the open ocean, between the heads of bays, or in the visible areas inside bays made up nearly half (48.7\%) of the 


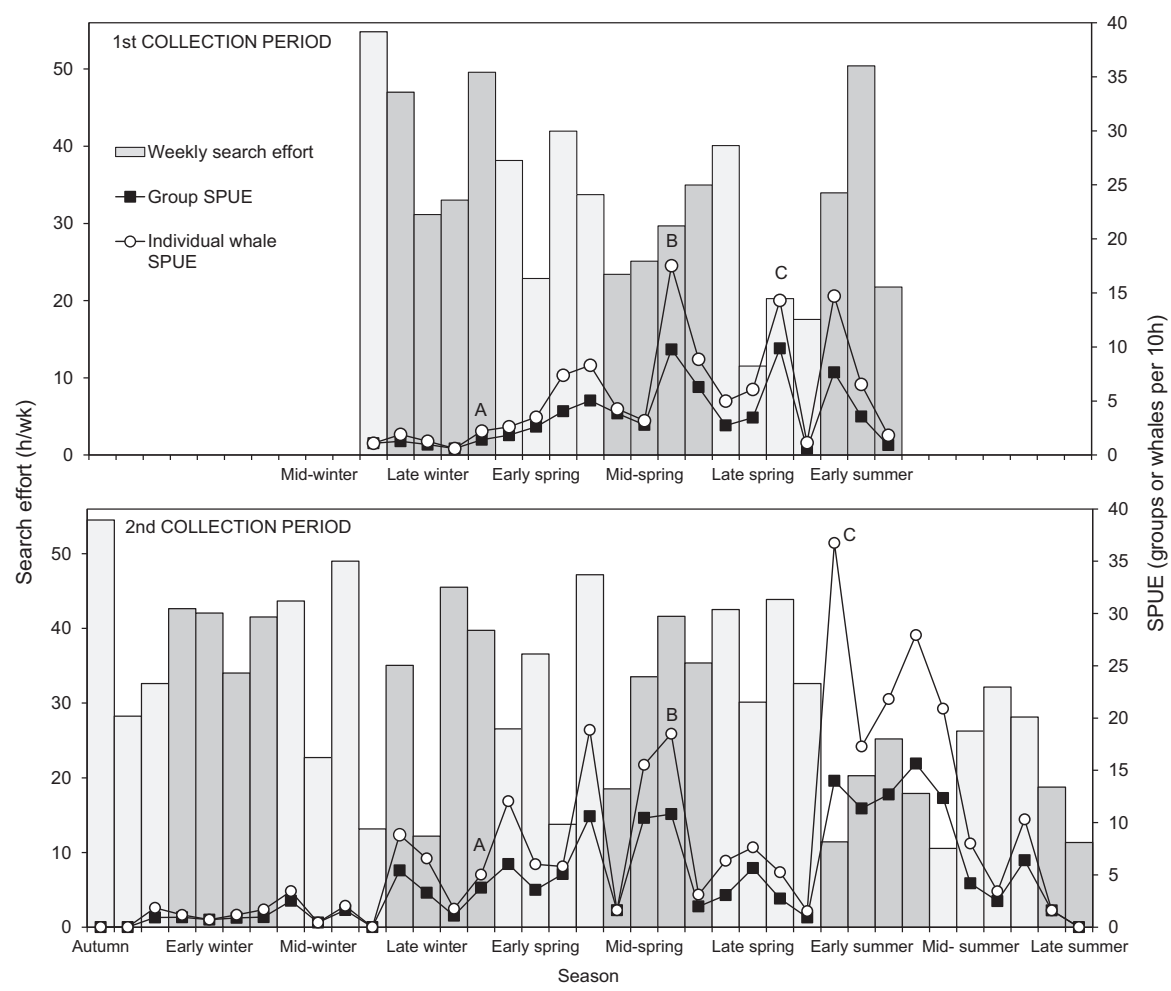

Figure 2. Sightings per unit effort (SPUE) of southern right whale groups and individuals (sum of best group size estimate) off North Head, Saldanha Bay, for two data collection periods (top: 24 July-20 December 2001; bottom: 6 May 2002-15 February 2003). Bars indicate total weekly search effort (hours) for each subseason (differential shading indicates different subseasons). Capital letters indicate phases that appear to be similar for the two collection periods: "A" shows the commencement of a steady increase in SPUE up to a first peak ("B") in spring. "C" indicates a second peak during late spring/early summer, after which sighting rates declined.

total. Eighty groups were located in Saldanha Bay/Langebaan Lagoon, four in Danger Bay, and one in Plankiesbaai $(n=85$; see Fig. $1 \mathrm{~b}$ for localities). Most remaining groups $(45.8 \%)$ were located $1-5 \mathrm{~km}$ from the shore, while only 25 groups $(5.6 \%)$ were spotted beyond $5 \mathrm{~km}$. However, the share of groups with a strongly inshore (in bays and $<1 \mathrm{~km}, n=219)$ and offshore distribution $(\geq 1 \mathrm{~km}, n=231)$ did not vary significantly from an expected even distribution ( $1: 1$ ratio) (Table $2, \chi^{2}=0.32, \mathrm{df}=1$, $P=0.572$ ).

Boat intercepts (Fig. 3) showed an even stronger nearshore distribution than shore sightings, with 49.6\% occurring inside bays (118 groups, of which 99 were sighted without assistance from the shore), compared to $18.9 \%$ of shore sightings. This suggests some nearshore bias for selection of such groups by the boat.

The overall mean distance for shore sightings, excluding those seen in the bays, was $2.14 \mathrm{~km} \pm 0.09 \mathrm{SE}$ (Table $2, n=365$ ) and the maximum distance recorded was $9.16 \mathrm{~km}$. A Kruskal-Wallis ANOVA by ranks showed a highly significant difference 
Table 1. Search effort, and sightings per unit effort (SPUE) by subseason for groups of southern right whale sighted at Saldanha Bay, South Africa $(n=$ number of monthly quartile subsamples).

\begin{tabular}{lcclccc}
$\quad$ Subseason & $n$ & $\begin{array}{c}\text { Mean SPUE } \\
\text { groups/10 h) } \pm \text { SE }\end{array}$ & $\begin{array}{c}\text { Min.-max. } \\
\text { (SPUE) }\end{array}$ & $\begin{array}{c}\text { Total hours } \\
\text { on watch }\end{array}$ & $\begin{array}{c}\text { Days on } \\
\text { watch }\end{array}$ & $\begin{array}{c}\text { Hours } \\
\text { per day } \\
\text { on watch }\end{array}$ \\
\hline $\begin{array}{l}\text { Autumn to } \\
\text { mid-winter }\end{array}$ & 12 & $0.84 \pm 0.21$ & $0-2.52$ & 459.09 & 69 & 6.65 \\
Late winter & 8 & $2.23 \pm 0.61$ & $0.61-5.42$ & 293.30 & 46 & 6.38 \\
Early spring & 8 & $4.85 \pm 0.95$ & $1.83-10.6$ & 260.80 & 38 & 6.86 \\
Mid-spring & 8 & $5.94 \pm 1.39$ & $1.62-10.81$ & 242.23 & 42 & 5.77 \\
Late spring & 8 & $3.63 \pm 1.05$ & $0.57-9.87$ & 238.63 & 35 & 6.82 \\
Early summer & 7 & $9.40 \pm 2.09$ & $0.92-15.64$ & 180.95 & 32 & 5.65 \\
$\begin{array}{l}\text { Mid- to late } \\
\text { summer }\end{array}$ & 6 & $4.50 \pm 1.81$ & $0-12.34$ & 127.18 & 20 & 6.36 \\
All seasons & 57 & $4.14 \pm 0.54$ & $0-15.64$ & $1,802.18$ & 282 & 6.39
\end{tabular}

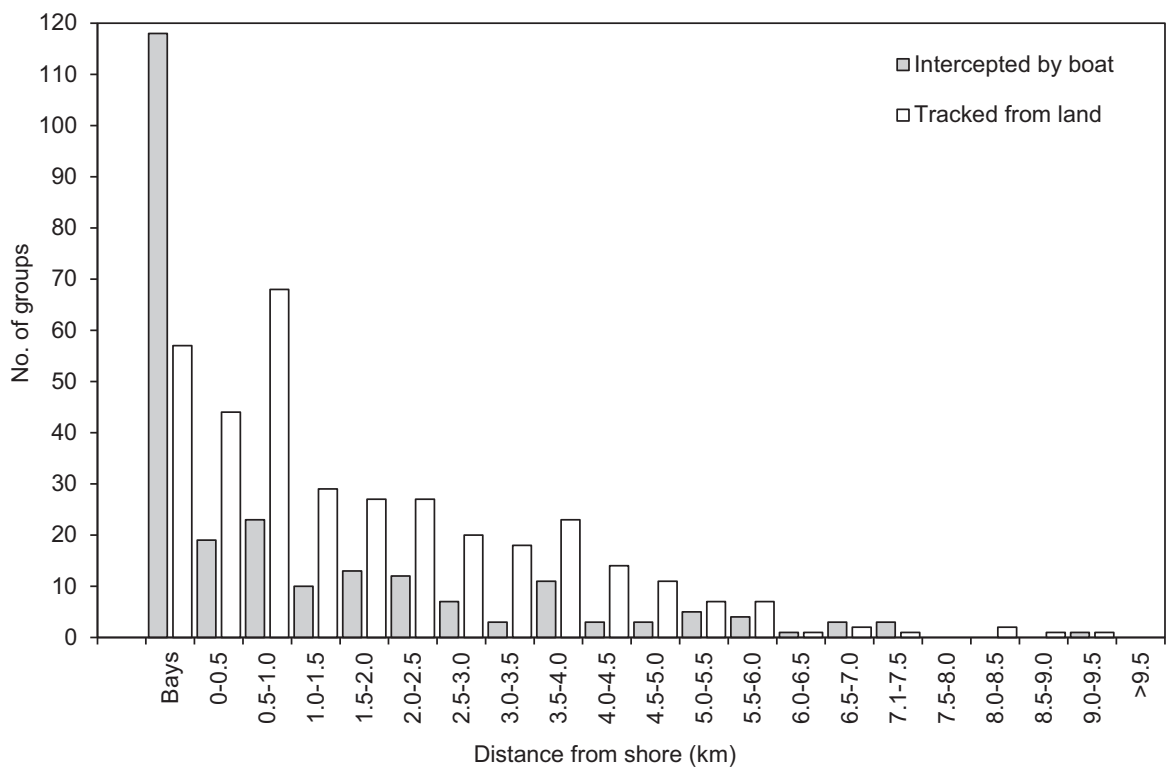

Figure 3. Distance distribution of southern right whale groups from the coast when tracked from the shore (calculated from first reliable theodolite fix), or intercepted by boat (GPS position) to the nearest "smoothed" shoreline $(\mathrm{km})$, or located inside major bays. Those 91 groups where we could confidently link land sightings and boat intercepts (see text) have been excluded from the land sample.

of distance from the shore between subseasons $(H=46.564, P<0.0001$, $\mathrm{df}=6, n=365)$ and a Dunn's multiple comparison post hoc test showed that summer sightings were significantly farther from shore than late winter and early, mid-, and 
Table 2. Summary of distance distribution from shore and movement parameters (net course, swimming speed, and linearity) by subseason of southern right whales tracked by theodolite from North Head, Saldanha Bay. Where groups outside bays or $>1 \mathrm{~km}$ and inside bays and/or $<1 \mathrm{~km}$ are reported on separately, the bay/nearshore component is given in square parentheses. Note that sample sizes for distance calculations are no. of groups with one reliable fix, and for movement parameters no. of groups with $>2$ fixes. Bold values indicate significant difference $(P<0.05)$ from the following statistical tests (see text for more details): mean distance and swimming speed—Dunn's multiple comparison (where* and ** indicate from which subseasons the bold value differs significantly); group distribution and linearity-Chi-square; net course-Rayleigh's test for circular uniformity. Direction of movement: $\mathrm{N}=\operatorname{north}\left(286^{\circ}-15^{\circ}\right) ; \mathrm{S}=$ south $\left(106^{\circ}-195^{\circ}\right) ; \mathrm{W}=$ west $\left(196^{\circ}-285^{\circ}\right) ; \mathrm{E}=$ east $\left(16^{\circ}-105^{\circ}\right)$.

\begin{tabular}{|c|c|c|c|c|c|c|c|c|}
\hline \multirow{2}{*}{$\begin{array}{l}\text { Distance or } \\
\text { movement } \\
\text { parameter }\end{array}$} & \multicolumn{8}{|c|}{ Subseason } \\
\hline & $\begin{array}{l}\text { Autumn to } \\
\text { mid-winter }\end{array}$ & Late winter & Early spring & Mid-spring & Late spring & Early summer & $\begin{array}{l}\text { Mid- to } \\
\text { late summer }\end{array}$ & All seasons \\
\hline $\begin{array}{l}n=\text { groups with } \\
1 \text { reliable } \\
\text { theodolite fix } \\
\text { [in bays] }\end{array}$ & $30[3]$ & $25[9]$ & $64\{26]$ & $71[22]$ & $41[14]$ & $94[7]$ & $40[4]$ & $365[85]$ \\
\hline $\begin{array}{l}\text { Distance from } \\
\text { shore }(\mathrm{km})\end{array}$ & & & & & & & & \\
\hline Mean \pm SE & $1.87 \pm 0.24$ & $1.08 \pm 0.18^{* / * *}$ & $1.84 \pm 0.22^{*}$ & $1.76 \pm 0.21^{*}$ & $1.86 \pm 0.29^{*}$ & $2.94 \pm \mathbf{0 . 1 8} *$ & $2.60 \pm 0.25^{* *}$ & $2.14 \pm 0.09$ \\
\hline Min.--max. & $0.22-4.97$ & $0.11-3.11$ & $0.09-6.80$ & $0.18-9.16$ & $0.14-8.36$ & $0.03-8.81$ & $0.10-6.63$ & $0.03-9.16$ \\
\hline $\begin{array}{l}\text { Distribution of } \\
\text { group }>1 \mathrm{~km} \\
{[<1 \mathrm{~km} \text { and }} \\
\text { bays }]\end{array}$ & $22[11]$ & $8[\mathbf{2 6}]$ & $33[57]$ & $37[\mathbf{5 6}]$ & $20[\mathbf{3 5}]$ & $79[22]$ & 32 [12] & 231 [219] \\
\hline $\begin{array}{l}n=\text { groups with } \\
>2 \text { fixes [in } \\
\text { bays] }\end{array}$ & $25[2]$ & $23[6]$ & $52[19]$ & $55[21]$ & $39[13]$ & $71[5]$ & $27[4]$ & $292[70]$ \\
\hline $\begin{array}{l}\text { Mean net course } \\
\text { of movement } \\
\text { ( }{ }^{\text {true }} \text { [bays } \\
\text { excluded] }\end{array}$ & 137.96 & 118.78 & 126.13 & 25.92 & 151.77 & 45.85 & 161.51 & 127.98 \\
\hline
\end{tabular}


Subseason

\begin{tabular}{|c|c|c|c|c|c|c|c|c|}
\hline \multirow{2}{*}{$\begin{array}{l}\text { Distance or } \\
\text { movement } \\
\text { parameter }\end{array}$} & \multicolumn{8}{|c|}{ Subseason } \\
\hline & $\begin{array}{l}\text { Autumn to } \\
\text { mid-winter }\end{array}$ & Late winter & Early spring & Mid-spring & Late spring & Early summer & $\begin{array}{l}\text { Mid- to } \\
\text { late summer }\end{array}$ & All seasons \\
\hline Direction of & $88 \% \mathrm{~S}$ & $47.8 \% \mathrm{~S}$ & $55.8 \% \mathrm{~S}$ & $34.5 \% \mathrm{~S}$ & $48.7 \% \mathrm{~S}$ & $38 \% \mathrm{~S}$ & $48.2 \% \mathrm{~S}$ & $47.9 \% \mathrm{~S}$ \\
\hline relative to & $4 \% \mathrm{E}$ & $17.4 \% \mathrm{E}$ & $15.4 \% \mathrm{E}$ & $16.4 \% \mathrm{E}$ & $7.7 \% \mathrm{E}$ & $9.9 \% \mathrm{~W}$ & $7.4 \% \mathrm{~W}$ & $12.7 \% \mathrm{E}$ \\
\hline $\begin{array}{l}\text { shoreline (\% } \\
\text { groups and } \\
\text { heading) [bays } \\
\text { excluded] }\end{array}$ & - & $4.4 \% \mathrm{~W}$ & $7.7 \% \mathrm{~W}$ & $5.5 \% \mathrm{~W}$ & $10.3 \% \mathrm{~W}$ & $15.5 \% \mathrm{E}$ & $3.7 \% \mathrm{E}$ & $7.2 \% \mathrm{~W}$ \\
\hline $\begin{array}{l}\text { Actual } \\
\text { swimming } \\
\text { speed }(\mathrm{km} / \mathrm{h})\end{array}$ & & & & & & & & \\
\hline Mean $\pm \mathrm{SE}$ & $4.11 \pm 0.37^{*}$ & $3.06 \pm 0.35$ & $2.34 \pm 0.15^{*}$ & $2.52 \pm 0.17^{*}$ & $2.93 \pm 0.19$ & $2.20 \pm 0.16 * / * *$ & $3.35 \pm 0.28 * *$ & $2.71 \pm 0.08$ \\
\hline $\begin{array}{l}\text { Min.-max. } \\
\text { Net swimming } \\
\text { speed }(\mathrm{km} / \mathrm{h})\end{array}$ & $0.58-7.60$ & $0.30-7.28$ & $0.33-7.64$ & $0.29-7.23$ & $0.30-5.60$ & $0.19-6.53$ & $0.89-6.14$ & $0.19-7.64$ \\
\hline Mean \pm SE & $3.99 \pm 0.38$ & $2.80 \pm 0.38$ & $1.93 \pm 0.16$ & $2.17 \pm 0.18$ & $2.63 \pm 0.21$ & $1.68 \pm 0.16$ & $2.71 \pm 0.32$ & $2.32 \pm 0.09$ \\
\hline $\begin{array}{l}\text { Linearity of } \\
\text { movement } \\
(\text { strong } \geq 0.95 / \\
\text { weak }<0.95)\end{array}$ & $21 / 6$ & $16 / 13$ & $35 / 36$ & $40 / 36$ & $27 / 25$ & $21 / \mathbf{5 5}$ & $10 / \mathbf{2 1}$ & 170/192 \\
\hline
\end{tabular}


late spring sightings respectively, while mid-to-late summer sightings were significantly farther from shore than late winter (Table 2). These two summer subseasons had mean distances farther than the overall average $(2.94 \mathrm{~km} \pm 0.18$ SE for early summer and $2.60 \mathrm{~km} \pm 0.25 \mathrm{SE}$ for mid- to late summer), despite mid-spring having the single farthest-from-shore sighting. Given the even distribution of groups between the inshore (bays and $<1 \mathrm{~km})$ and offshore $(>1 \mathrm{~km}$, see above) we tested whether this distribution was maintained during all subseasons. This was rejected for five of the subseasons, with significantly more groups being seen inshore in late winter $\left(\chi^{2}=9.53, P=0.002\right)$, mid-spring $\left(\chi^{2}=3.88, P=0.049\right)$ and late spring $\left(\chi^{2}=4.09, P=0.043\right)$, and more groups offshore in early summer $\left(\chi^{2}=32.17\right.$, $P=0.0001)$ and mid- to late summer $\left(\chi^{2}=9.09, P=0.0026\right)$ (Table 2$)$.

\section{Trackline Analysis}

Three or more reliable fixes were obtained for 362 right whale groups. Groups were tracked on average for $1.02 \mathrm{~h} \pm 0.04$ (SE), the shortest track lasting only 4 min and the longest $5.64 \mathrm{~h}$. Because southern right whales on the south coast show a preference for sheltered bays (Elwen and Best 2004a), and given the prominence of the bay-dwelling component as shown above (Table 2, Fig. 3), movement parameters were compared where possible between groups tracked inside and outside the major bays.

\section{Directionality}

Since movement inside the bays would be constrained by topography, we plotted the calculated net courses separately for groups inside $(n=70)$ and outside bays $(n=$ 292) (Fig. 4). This showed that while there was strong bimodality in directionality for the open ocean whales, there was no clearly discernible pattern for those in bays. The axis between the two directional peaks (about $330^{\circ}-150^{\circ}$ ) for offshore whales corresponds closely with the orientation of the coastline at Saldanha Bay. The mean angle of direction (based on net course) for all whale groups in bays was $33^{\circ}$ and Rayleigh's test for circular uniformity (Zar 1996) showed that their direction of movement did not differ significantly from a random distribution (Rayleigh's $R=11.798, Z=1.988, P>0.05$ ), while whales tracked outside of the bays showed significant southeasterly directionality $\left(128^{\circ}\right.$, Rayleigh's $R=48.261, Z=7.976$, $P<0.05)$. We therefore excluded groups inside bays when examining the subseasonal directionality of movement. Groups were binned in one of four $90^{\circ}$ quadrants (with a $30^{\circ}$ offset to the west from true north, to compensate for the direction of the coast): (1) northbound $\left(286^{\circ}-15^{\circ}\right)$; (2) southbound $\left(106^{\circ}-195^{\circ}\right)$; (3) offshore (westward, $196^{\circ}-285^{\circ}$ ); and (4) onshore (eastward, $16^{\circ}-105^{\circ}$ ). A subseasonal breakdown of proportions of groups moving into these directions (Table 2) showed no offshore movement during autumn to mid-winter, when southward moving groups dominated. Southbound groups were also predominant in late winter, early spring, and late spring. South- and northbound groups were more or less equal in the remaining seasons except for mid-spring, where the latter were in the majority. Groups heading offshore represented $\leq 10 \%$ during any subseason, although there were slightly more in late spring and early summer. The proportion of groups moving onshore (eastward) was small during both autumn to mid-winter, and mid- to late summer $(<5 \%)$, while it was more or less constant at about $18 \%$ of groups for the remainder of subseasons, except late spring $(7.7 \%)$. 


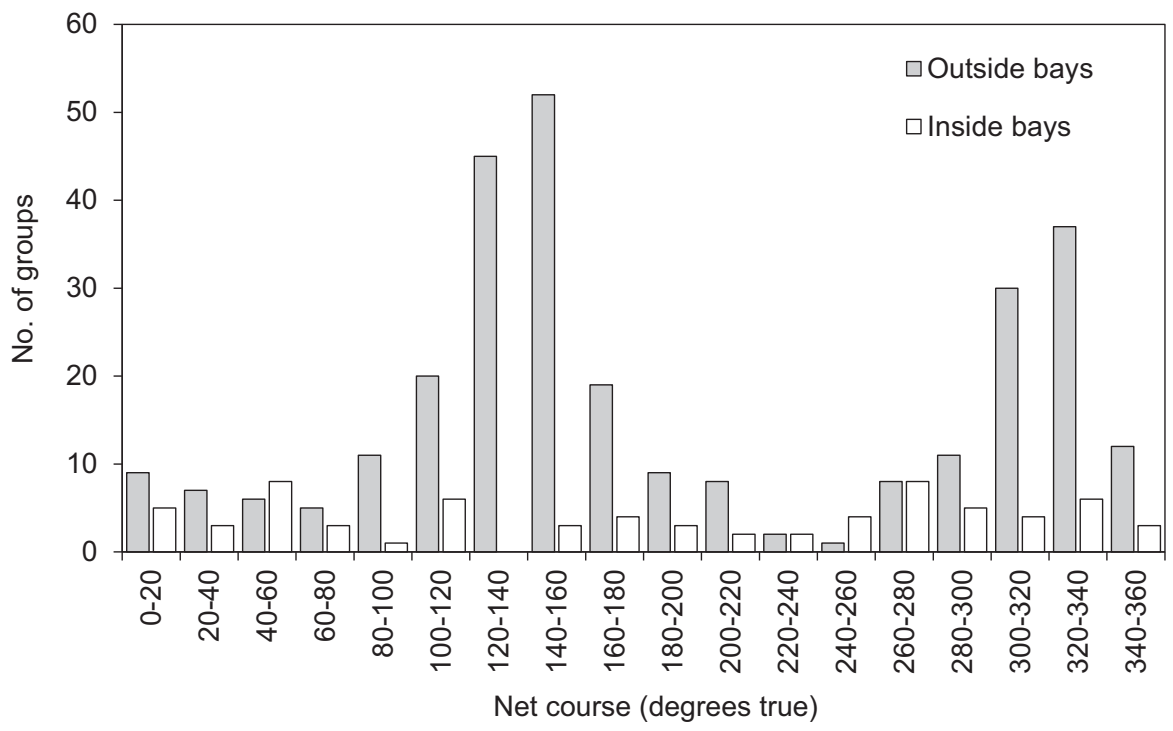

Figure 4. Frequency distribution of net course of 362 southern right whale groups tracked from North Head, Saldanha Bay, 292 in the open ocean and 70 inside bays.

The mean course (Table 2) further confirmed changes in direction of travel between subseasons. Starting in early spring, it alternated on four occasions in successive subseasons between an alongshore to slightly onshore southerly movement, and a northerly or northeasterly (onshore) direction (Table 2). In three of the four subseasons (viz, autumn to mid-winter, early and late spring), the distribution of directionality was found to be significantly different from uniformity (Table 2, Rayleigh's test for circular uniformity $P<0.05$, Zar 1996), with a southeasterly predominance.

\section{Linearity of Movement}

Nearly half (47\%) of all tracked whale groups $(n=362$, including those in bays) had linearity of movement values between 0.95 and 1.0, forming the only prominent peak in a frequency distribution. Such groups moving in an almost straight line were regarded as showing "strong" linearity and those with values less than 0.95 , "weak" linearity. When examined by subseason (Table 2) there was an overall decline in the proportion of groups exhibiting strong linearity with advancing subseason. Thus, from autumn to mid-winter the proportion of groups with strong linearity was significantly greater than parity $\left(\chi^{2}=8.33, \mathrm{df}=1, P<0.004\right)$ while in the early sum$\operatorname{mer}\left(\chi^{2}=15.21, \mathrm{df}=1, P<0.0001\right)$ and mid- to late summer $\left(\chi^{2}=3.90, \mathrm{df}=1\right.$, $P<0.048$ ) the groups with weak linearity predominated (Table 2$)$. There was no significant difference ( $t$-test, $t=-0.438, \mathrm{df}=360, P>0.662)$ between mean linearity of groups inside (0.82 $\pm 0.24 \mathrm{SE}, n=70)$ and outside $(0.83 \pm 0.013 \mathrm{SE}, n=292)$ bays.

\section{Swimming Speed}

Actual swimming ( $=$ leg) speed for all groups ranged from 0.2 to a maximum of $7.6 \mathrm{~km} / \mathrm{h}$ with a mean of $2.71 \mathrm{~km} / \mathrm{h} \pm 0.08 \mathrm{SE}$, while net speed ranged from almost 
stationary $(0.03 \mathrm{~km} / \mathrm{h})$ to $7.7 \mathrm{~km} / \mathrm{h}$ with a mean of $2.32 \mathrm{~km} / \mathrm{h} \pm 0.09 \mathrm{SE}$ (Table 2). The net speed of the majority of groups fell in the $0.5-3.5 \mathrm{~km} / \mathrm{h}$ range (Table 2). Kruskal-Wallis ANOVA showed leg speeds across subseasons to differ significantly $(H=35.872, n=362, P<0.0001)$. The highest mean actual swimming speed was recorded in autumn to mid-winter at $4.11 \mathrm{~km} / \mathrm{h} \pm 0.37 \mathrm{SE}$, which differed significantly from early spring $(Z=4.222, P<0.001)$, mid-spring $(Z=3.830, P<0.003)$, and early summer $(Z=4.813, P<0.0001)$. Furthermore, early summer differed significantly from mid- to late summer $(Z=3.528, P<0.009)$ (Dunn's multiple comparison post hoc test); the latter subseason had the second highest recorded mean swimming speed. The lowest means for both actual and net speeds ( 2.2 and $1.68 \mathrm{~km} /$ $\mathrm{h}$, respectively) were measured in early summer, the subseason when the lowest minimum net speed was recorded (Table 2). Both actual and net swimming speed showed a significant negative relationship with duration of the track (leg speed: $r=-0.203$, $P<0.0001$; net speed: $r=-0.278, P<0.0001)$. This may be an artifact of sampling. Groups tracked inside bays swam significantly slower $(2.01 \mathrm{~km} / \mathrm{h} \pm 0.14 \mathrm{SE}, n=70)$ than those in open water $(2.88 \mathrm{~km} / \mathrm{h} \pm 0.094 \mathrm{SE}, n=292)(t$-test, $t=4.258, \mathrm{df}=$ $360, P<0.0001)$. Actual swimming speed showed a significant negative correlation with group size $(r=-0.132, P<0.011)$. Average speed declined from $3.23 \pm 0.144$ $\mathrm{km} / \mathrm{h} \mathrm{SE}$ in singles $(n=144)$ to $2.59 \pm 0.116 \mathrm{~km} / \mathrm{h}$ SE for duos $(n=145)$ and 1.92 $\pm 0.135 \mathrm{~km} / \mathrm{h} \mathrm{SE}$ in groups of three or more $(n=73)$.

\section{Group Characteristics and Behavior}

Group size-Of the 238 southern right whale groups intercepted by boat, and the 450 groups with a reliable theodolite fix seen from land, it was possible to confidently link 91, thus providing two independent group size estimates from different observation platforms (Fig. 5). Although the mean sizes for these 91 groups, as estimated

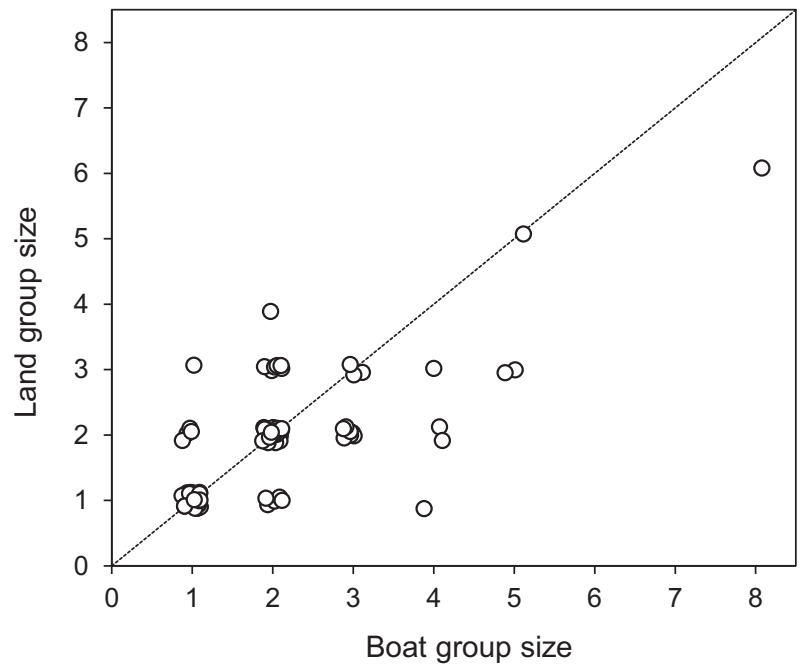

Figure 5. Relationship between group sizes estimated from boat and land for the same 91 groups of southern right whales. A random offset factor of 0.25 has been in introduced to group sizes to make overlapping points more visible. Dashed line indicates perfect fit. 
from the boat $(1.97 \pm 0.12 \mathrm{SE})$ and from the land $(1.84 \pm 0.097 \mathrm{SE})$ did not differ significantly ( $t$-test for dependent samples, $t=1.5613$, df $=90, P>0.122$ ), it appears from the figure that land-based observers tended to underestimate group sizes of three or more (assuming the boat-based estimates were more accurate). We therefore limit our results and discussion about group size to the 238 observations made from the boat, while acknowledging the nearshore bias of boat intercepts (see above).

The mean group size for all boat intercepts was $2.18 \pm 0.11 \mathrm{SE}$ (Table 3) with the maximum estimated at 12 . We encountered singletons most frequently overall $(n=102)$ followed by duos $(n=75)$ and trios $(n=27)$. Groups of four or more were intercepted 34 times. The mean group size inside bays $(2.48 \pm 0.182 \mathrm{SE}, n=118)$ was significantly bigger than those outside (1.88 $\pm 0.109 \mathrm{SE}, n=120)$ ( $t$-test, $t=$ $-2.84, \mathrm{df}=236, P<0.005)$. An examination of group size by subseason (Table 3 ) showed a more or less equal proportion of singletons and duos in autumn to midwinter. While duos were less frequently encountered, groups of four and more became a regular feature from late winter onward.

Behavior and group composition-We did not record behavior for 19 of the 450 groups $(4.2 \%)$, possibly because of the short duration of their sightings or nondescript behavior; these were added to the category "passive behavior" (Fig. 6). We specifically recorded groups as "surface active groups" (SAGs) 21 times from the boat, and 76 times from the shore. Most SAGs intercepted by boat consisted of duos $(n=8)$ of animals, followed by trios $(n=5)$ and two groups of five. SAGs started appearing from late winter (Table 3) and they were consistently common from early spring through to early summer. SAGs virtually disappeared in mid- to late summer and were replaced by milling groups and individual surface activity during this season (Fig. 6). SAGs intercepted by boat were located predominantly inside Saldanha Bay (14 out of 21 groups, Fig. 7).

We intercepted cow-calf pairs by boat on 18 occasions during the study period, two of which were resightings of the same pairs. One of these was first seen unaccompanied, and again later on the same day as part of a group of seven individuals, with defecations observed. This was one of the four instances where cow-calf pairs were associated with other whales in larger groups. One of these showed a high degree of surface activity, with other individuals apparently harassing the cow-calf pair.

Calves seen had estimated lengths of 4-9 $\mathrm{m}$. We examined the photographs of the cow-calf pair with the smallest calf (seen on 22 December 2002) to help assess its possible age. The cow was matched to the south coast aerial survey where it was first seen on 9 October $2002\left(34^{\circ} 02.12^{\prime} \mathrm{S}, 23^{\circ} 23.71^{\prime} \mathrm{E}\right)$ with a newborn calf. Thus, the calf was at least 10.5 wk old when seen off Saldanha Bay and by then had a clearly developed callosity pattern.

Three of the cow-calf pairs were located inside Saldanha Bay (Fig. 7) while the others were seen in shallow water ( $<80 \mathrm{~m}$ depth), mostly less than $3 \mathrm{~km}$ from the shore. All cow-calf pairs were seen in spring or summer (Fig. 6) except one pair in autumn to mid-winter (May) where the calf was large, presumably from the previous year, and the cow appeared to be in poor physical condition.

We observed defecations from the boat on 16 occasions (Table 4), including once by a cow accompanied by a calf (18 December 2002, No. 9) and three times associated with apparent feeding behavior (Table 4, Nos. 18, 19, 20). All defecations were seen in November/December 2002 and January 2003. Behaviors that were interpreted as relating to feeding included the flushing of baleen and swimming with the mouth open, or frequent and short fluke-up dives, often in conjunction with the observation of zooplankton in the water. Feeding behavior was sometimes associated 
Table 3. Details of southern right whale group characteristics by subseason recorded during boat intercepts or tracked from land at Saldanha Bay. Mean and maximum group sizes are based on best group size estimates; SAGs = Surface Active Groups (see text for definition). Note that for 91 of the groups, a group size estimate was made from both observation platforms (see Fig. 5).

\begin{tabular}{|c|c|c|c|c|c|c|c|c|c|}
\hline & \multicolumn{8}{|c|}{ Subseason } \\
\hline & & $\begin{array}{l}\text { Autumn to } \\
\text { mid-winter }\end{array}$ & Late winter & Early spring & Mid-spring & Late spring & Early summer & $\begin{array}{l}\text { Mid- to } \\
\text { late summer }\end{array}$ & All seasons \\
\hline \multirow{2}{*}{$\begin{array}{l}\text { Boat group } \\
\text { size }\end{array}$} & $n$ & 17 & 26 & 62 & 31 & 33 & 38 & 34 & 241 \\
\hline & $\begin{array}{l}\text { Mean } \pm \text { SE } \\
\text { Maximum }\end{array}$ & $\begin{array}{l}1.65 \pm 0.24 \\
5\end{array}$ & $\begin{array}{l}2.19 \pm 0.32 \\
6\end{array}$ & $\begin{array}{l}2.69 \pm 0.27 \\
12\end{array}$ & $\begin{array}{l}2.42 \pm 0.30 \\
8\end{array}$ & $\begin{array}{l}1.88 \pm 0.22 \\
7\end{array}$ & $\begin{array}{l}2.03 \pm 0.24 \\
9\end{array}$ & $\begin{array}{l}1.71 \pm 0.20 \\
7\end{array}$ & $\begin{array}{l}2.17 \pm 0.11 \\
12\end{array}$ \\
\hline \multirow{2}{*}{$\begin{array}{l}\text { Land group } \\
\text { size }\end{array}$} & $n$ & 33 & 34 & 90 & 93 & 55 & 101 & 44 & 450 \\
\hline & $\begin{array}{l}\text { Mean } \pm \text { SE } \\
\text { Maximum }\end{array}$ & $\begin{array}{l}1.36 \pm 0.09 \\
2\end{array}$ & $\begin{array}{l}1.65 \pm 0.11 \\
3\end{array}$ & $\begin{array}{l}1.86 \pm 0.09 \\
5\end{array}$ & $\begin{array}{l}1.74 \pm 0.10 \\
6\end{array}$ & $\begin{array}{l}1.84 \pm 0.13 \\
5\end{array}$ & $\begin{array}{l}2.08 \pm 0.10 \\
6\end{array}$ & $\begin{array}{l}1.73 \pm 0.11 \\
4\end{array}$ & $\begin{array}{l}1.82 \pm 0.04 \\
6\end{array}$ \\
\hline \multirow{4}{*}{$\begin{array}{l}\text { Proportion } \\
\text { of boat } \\
\text { groups } \\
\text { of size }\end{array}$} & 1 & $53 \%$ & $50 \%$ & $33 \%$ & $35 \%$ & $48 \%$ & $42 \%$ & $53 \%$ & $43 \%$ \\
\hline & 2 & $41 \%$ & $27 \%$ & $26 \%$ & $29 \%$ & $30 \%$ & $37 \%$ & $38 \%$ & $32 \%$ \\
\hline & 3 & $0 \%$ & $0 \%$ & $18 \%$ & $16 \%$ & $15 \%$ & $13 \%$ & $3 \%$ & $11 \%$ \\
\hline & $\geq 4$ & $6 \%$ & $23 \%$ & $23 \%$ & $19 \%$ & $6 \%$ & $8 \%$ & $6 \%$ & $14 \%$ \\
\hline \multirow[t]{2}{*}{$\begin{array}{l}\text { Number } \\
\text { SAGs }\end{array}$} & Intercepted & 0 & 2 & 5 & 2 & 6 & 5 & 1 & 21 \\
\hline & Seen from & 1 & 4 & 19 & 19 & 13 & 20 & 0 & 76 \\
\hline
\end{tabular}




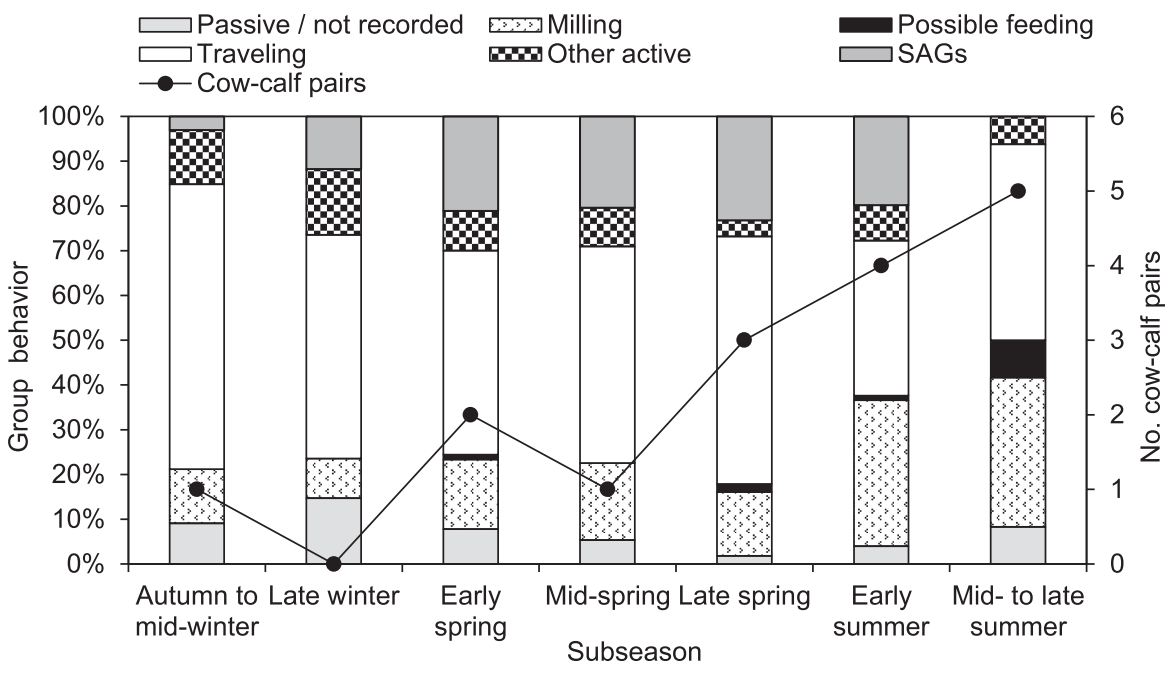

Figure 6. Seasonal breakdown of predominant behavior attributed to 450 southern right whales groups seen from North Head, Saldanha Bay, and number of cow-calf pairs intercepted by boat during each season ( $n=16$, two known resightings excluded).

with surface activity, reminiscent of sexual activity related to typical SAGs, although this was more likely to be individual surface activity by members of the larger feeding groups (see below). The first two of the nine intercepts suspected of feeding were observed in spring (in September 2002 by a small animal, and in October 2002 in association with humpback whales), while the majority of observations were in early summer (four times) and mid-summer (three) (Table 4). Possible feeding groups ranged in size from singletons up to five individuals, with only two groups larger than three, and dyads the most commonly seen (four times). Feeding groups were seen in water depths ranging from 8.3 to $100 \mathrm{~m}$ and were all located outside Saldanha Bay, with the exception of the one seen on 13 September 2002 (Fig. 7, No. 1), near the entrance of Langebaan Lagoon. Twice, at shallower depths (21.8 and $43.1 \mathrm{~m}$; Fig. 7, Nos. 4 and 20, respectively) patches of what appeared to be sediment particles rose to the surface during bouts of repetitive short dives, suggesting feeding close to the bottom.

\section{Opportunistic Evidence for Regional Scale Movement}

Although identification of individual whales is not covered in this paper, we recorded incidental evidence of transit from the south to the west coast in the same season in two instances. The first instance involved the cow with a small calf mentioned above, that moved from Plettenberg Bay (about $670 \mathrm{~km}$ south and east of Saldanha Bay, next to Nature's Valley) on 9 October to our study area on 22 December. In the second instance, we photographed a right whale twice during midsummer (16 and 23 December 2001) with green nylon line and torn black netting wrapped around its tail stock and through the notch of its flukes, with a number of colored floats trailing on about $15 \mathrm{~m}$ of rope. This entangled whale was recognized from a photograph taken on 9 October 2001 off Mossel Bay (Fig. 1a) during the annual aerial survey, about $530 \mathrm{~km}$ to the south and east of Saldanha Bay. 


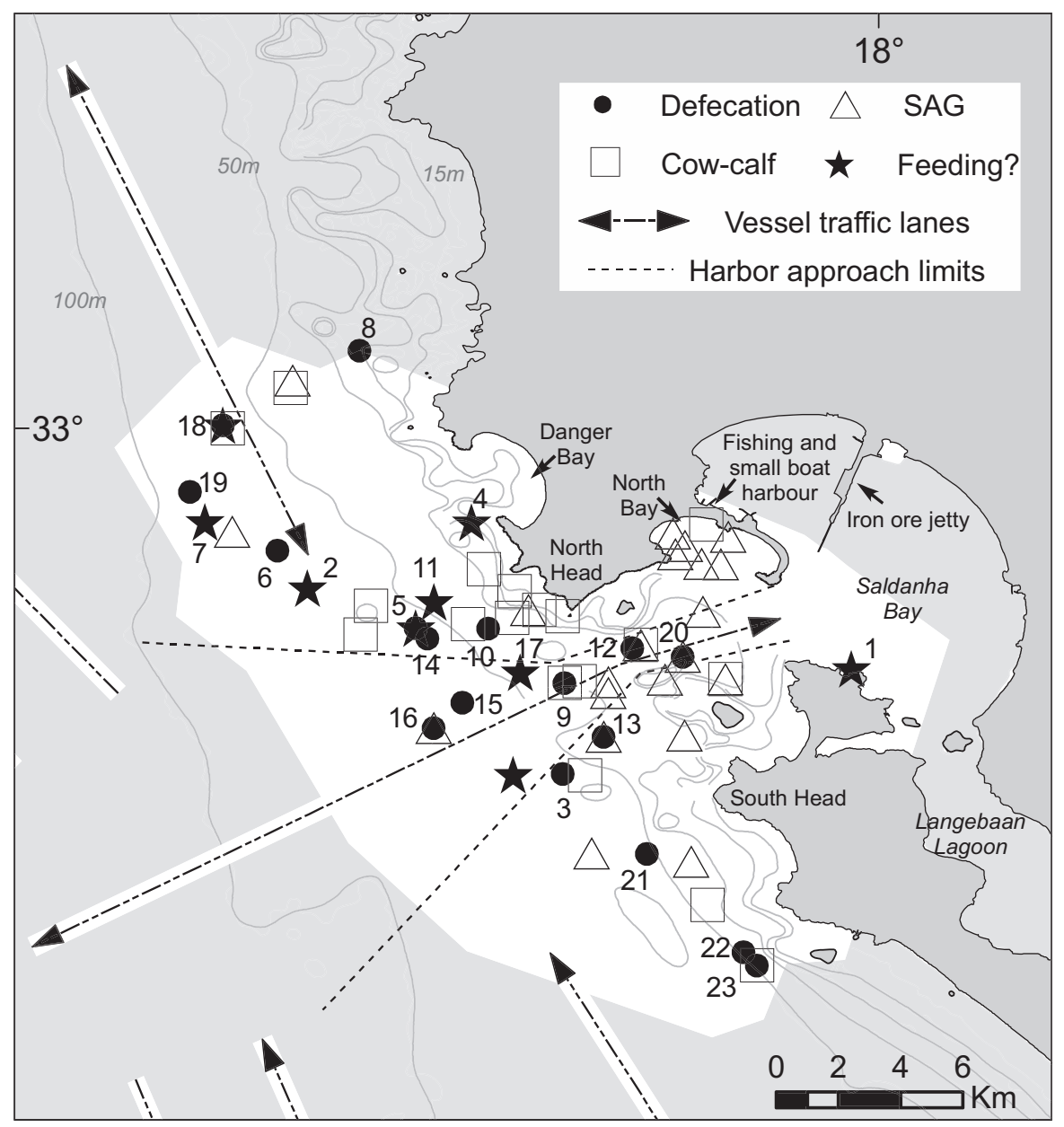

Figure 7. Detail of Saldanha Bay and port showing localities of specific group and behavioral observations. Numbers correspond to those in Table 4, or mentioned in the text. Note that there may be overlap between marker symbols due to more than one type of behavior recorded during a boat encounter. White area in ocean shows spatial extent of all right whale groups tracked or encountered by boat during our study (also see Fig. 1).

\section{DisCUSSION}

Our study represents research effort that greatly exceeds in duration and seasonal coverage, any preceding shore-based observations within the current and known historic southern right whale range in South African waters. In particular, it provides insight into the utilization of the under-surveyed west coast region by right whales. To help focus our discussion we: (1) explore the seasonality and extended presence of right whales on the west coast, compared to what is known from previous studies in the region; (2) summarize our observations in relation to group composition, movement parameters and behavior; (3) reflect on the west coast's suitability as a right whale calving and nursery area when compared to the better surveyed south coast, 
and elsewhere; and (4) discuss the importance of the west coast as a right whale habitat, given the growing evidence of its function as a feeding ground (Best 2006 , Mate et al. 2011). We do this against the backdrop of the different physical and oceanographic features of the two coasts, and their possible influence on whale distribution and behavior.

\section{Year-round Presence and Seasonal Abundance}

Based on historical catches and occurrence at nearby St. Helena Bay (Richards and Du Pasquier 1989, Best 2006a) the presence of southern right whales at our study site virtually throughout the study period was perhaps not entirely unexpected. However, the combination of local population depletion during the 18th century (Best $2006 a$ ), the low survey effort off the west coast, and the strong focus on the south coast all contributed to mask the importance of the region as a right whale feeding habitat until recently. Between 1970 and 1986 when the aerial survey extended up the west coast, sightings south of $32^{\circ} \mathrm{S}$ and west of Cape Point in the months of September/October (early to mid-spring) accounted for only $10 \%$ of the total sightings recorded in the entire survey area (Best 1990). The sighting rates for right whales recorded at Cape Columbine in $424 \mathrm{~h}$ of watching in October/November 1993 (Best et al. 1995), 1.6 groups/10 h and 2.8 whales/10 h, were about one-third of the group and individual SPUE that we recorded at Saldanha for the same months ( 4.8 groups/10 h and 8.9 whales/10 h, respectively) in 2001/2002. This would represent an increase rate of $13 \%$ p.a. - about double that of the estimated overall population increase (ca. $7 \%$ p.a., Brandão et al. 2010). Thus, the increased incidence of right whales on the west coast is not only as a result of overall population growth, but also reflects local and seasonal movement patterns.

As found in two earlier shore-based studies on the south coast-Walker Bay (Best 1970) and De Hoop (Best and Scott 1993) - our observations at Saldanha Bay showed that right whales first start to appear in autumn (April/May). Numbers then increase to a peak in early and mid-spring (September/October), the same time as the annual south coast aerial survey, which is intended to coincide with the close of the calving season to achieve optimal photographic coverage of cow-calf pairs (Best et al. 2001). From late spring (November) the whales start to leave the bays on the south coast; the timing of this decline in abundance agrees with the period that has been described elsewhere (e.g., Australia, Burnell and Bryden 1997) as the onset of the migration away from the coast, or at least the beginning of an alongshore dispersal prior to the main migration. However, in contrast to the south coast, this decline in late spring/early summer was short-lived off Saldanha, when we recorded a sharp increase in the mean SPUE in December, to an overall high of nearly a group every hour. But where do these whales come from?

Southern right whales are known to be highly mobile and long-range movements between coastlines of different continents or islands (e.g., between Australia and New Zealand, Pirzl et al. 2009; and around New Zealand, Carroll et al. 2011), or from the coast to pelagic feeding grounds are commonplace (Best et al. 1993, Rowntree et al. 2001, Mate et al. 2011). Movements at a smaller scale (along the same coastline) have been described from Australia (Burnell and Bryden 1997) and the South African annual aerial survey data have suggested a dispersal of cow-calf pairs over short distances (about 30-40 km) in a westerly direction, normally accomplished within one day (Best 2000). More recently, a satellite telemetry study with right whales tagged at localities on the west and the south coasts revealed local movement patterns 
Table 4. Date, time, and description of apparent feeding behavior and defecations by southern right whales observed during boat intercepts around Saldanha Bay, South Africa, 2001-2003. Sea Surface Temperature (SST) measured by hull mounted sensor. Numbers in first column correspond to those in Figure 7.

\begin{tabular}{|c|c|c|c|c|c|c|}
\hline No. & Date & Time & $\begin{array}{l}\text { Group } \\
\text { size }\end{array}$ & Description and behavior & $\begin{array}{l}\text { Depth } \\
(\mathrm{m})\end{array}$ & $\begin{array}{l}\text { SST } \\
\left({ }^{\circ} \mathrm{C}\right) \\
\end{array}$ \\
\hline 1 & 13 September 2002 & 0839 & 1 & $\begin{array}{l}\text { Possible feeding. Smallish } \\
(8 \mathrm{~m}) \text { animal; mouth open, } \\
\text { swimming to-and-fro while } \\
\text { arching back. }\end{array}$ & 8.3 & 16 \\
\hline 2 & 17 October 2002 & 1624 & 2 & $\begin{array}{l}\text { Possible feeding. With } \\
\text { humpback whales, breaching at } \\
\text { same time; one right whale } \\
\text { seemed to lunge with open } \\
\text { mouth, zooplankton visible } \\
\text { in water. }\end{array}$ & 85.5 & 17.5 \\
\hline 3 & 11 November 2002 & 1509 & 1 & Defecation. & 70.1 & 14.1 \\
\hline 4 & 5 December 2002 & 1154 & 2 & $\begin{array}{l}\text { Possible feeding. Repeated short } \\
\text { dives (ca. } 5 \text { min) at mouth of } \\
\text { Danger Bay. Sediment particles } \\
\text { came to surface; one animal } \\
\text { carried satellite tag. }\end{array}$ & 21.8 & 12.2 \\
\hline 5 & 6 December 2002 & 0756 & 5 & $\begin{array}{l}\text { Possible feeding. Frequent } \\
\text { vertical dives after } 1-3 \text { blows on } \\
\text { surface, some baleen shown at } \\
\text { surfacing, dives lasting less than } \\
3 \text { min; one individual with } \\
\text { remnant satellite tag. }\end{array}$ & 63 & 12.5 \\
\hline 6 & 6 December 2002 & 1124 & 2 & Defecation. & 85 & 13.7 \\
\hline 7 & 6 December 2002 & 1250 & 1 & Possible feeding, vertical dives. & 92.8 & 15.5 \\
\hline 8 & 16 December 2002 & 1213 & 3 & $\begin{array}{l}\text { Defecation; one individual } \\
\text { entangled, net caught around } \\
\text { peduncle and through fluke } \\
\text { notch, yellow floats and black } \\
\text { netting. Animal sighted earlier } \\
\text { on aerial survey and resighted } \\
\text { later in season. }\end{array}$ & 34.5 & 16.8 \\
\hline 9 & 18 December 2002 & 1100 & 2 & $\begin{array}{l}\text { Defecation. Cow of mother-calf } \\
\text { pair. }\end{array}$ & 56.8 & 17.2 \\
\hline 10 & 18 December 2002 & 1136 & 1 & Defecation. & 47.2 & 18.5 \\
\hline 11 & 18 December 2002 & 1223 & 1 & Possible feeding. Flushed baleen. & 49.8 & 18.7 \\
\hline 12 & 20 December 2002 & 1125 & 2 & Defecation. & 45.1 & 19.6 \\
\hline 13 & 20 December 2002 & 1320 & 2 & Defecation. SAG. & 57.6 & 18.4 \\
\hline 14 & 23 December 2002 & 1301 & 3 & Defecation. & 65.3 & 20.8 \\
\hline 15 & 23 December 2002 & 1636 & 1 & Defecation. & 67.5 & 20.6 \\
\hline 16 & 23 December 2002 & 1654 & 2 & $\begin{array}{l}\text { Defecation. SAG. Same } \\
\text { entangled animal as above. }\end{array}$ & 67.6 & 20 \\
\hline 17 & 10 January 2003 & 1543 & 2 & Possible feeding. & 57.6 & 18.1 \\
\hline 18 & 13 January 2003 & 1610 & 1 & $\begin{array}{l}\text { Defecation during spy-hop: } \\
\text { groaned and then defecated. } \\
\text { Also opened mouth, apparently } \\
\text { skimming and flushing baleen. }\end{array}$ & 77.7 & 14.6 \\
\hline
\end{tabular}




\begin{tabular}{|c|c|c|c|c|c|c|}
\hline No. & Date & Time & $\begin{array}{l}\text { Group } \\
\text { size }\end{array}$ & Description and behavior & $\begin{array}{l}\text { Depth } \\
(\mathrm{m})\end{array}$ & $\begin{array}{l}\text { SST } \\
\left({ }^{\circ} \mathrm{C}\right)\end{array}$ \\
\hline 19 & 14 January 2003 & 1510 & 2 & Defecation. SAG. & 100 & 16.7 \\
\hline 20 & 24 January 2003 & 1407 & 3 & $\begin{array}{l}\text { Defecation/possible feeding. All } \\
\text { animals doing dives of } c a \text {. } 3 \\
\text { min, erratic surfacing, could see } \\
\text { brown patches coming to } \\
\text { surface after dives-possible } \\
\text { feeding near bottom. Baleen } \\
\text { flushing also seen. }\end{array}$ & 43.1 & 18.5 \\
\hline 21 & 31 January 2003 & 1421 & 1 & Defecation. & 57 & 14.8 \\
\hline 22 & 31 January 2003 & 1545 & 4 & Defecation. & 48.7 & 14.8 \\
\hline 23 & 31 January 2003 & 1614 & 7 & $\begin{array}{l}\text { Multiple defecations; group } \\
\text { includes cow-calf pair. }\end{array}$ & 50 & 14.3 \\
\hline
\end{tabular}

to be more complex than a simple westward movement late in the season (Mate $e t$ al. 2011). These included movement of a tagged cow with a calf (on 11 October 2001, Best and Mate 2007) from St. Sebastian Bay westward to Walker Bay in $57 \mathrm{~d}$ (Mate et al. 2011). This cow, with the satellite tag still embedded but without an aerial, was resighted off Saldanha Bay on 5 December 2002 as part of a feeding group, offering a suggestion of its possible destination after the tag stopped transmitting the previous year (see Best and Mate 2007). East-to-west transits were also seen for two other tagged whales (a male and unaccompanied female) from St. Sebastian Bay to the west coast (Mate et al. 2011), a movement pattern shared by our two opportunistic sightings of the small calf and entangled whale (see above). Satellite tracking did also reveal movement in the opposite direction: two whales, a male and a female, tagged off Saldanha in late September traveled south and then east to False Bay and St. Sebastian Bay respectively. Another three male whales tagged off Saldanha in late September moved northwards into St. Helena Bay where they remained in the vicinity for up to $100 \mathrm{~d}$ before leaving the coast.

These variable movement patterns suggest that there is considerable exchange between the south and west coasts in late spring/early summer, but possibly also from destinations further north along the west coast, including the coast of Namibia. Right whale sightings remain rare off Namibia, although their seasonal distribution closely resembles patterns on the South African south coast, with peak numbers in September (Roux et al. 2001). The stock structure and relationship between Namibian and South African right whales is not well understood but there is recent substantial evidence for connectivity between these two areas (Roux et al. 2011).

\section{Right Whale Movement and Behavior at Saldanha Bay}

When considered in combination with seasonality of abundance, behavior, movement and distribution from shore, southern right whale occurrence at Saldanha Bay suggests three distinct episodes (see Table 2, 3):

(1) Autumn and winter subseasons are characterized by low abundance and small groups (1-3 individuals) traveling fast in a predominantly southerly direction, with stronger linearity of movement (decreasing between early and late winter) 
that is highly suggestive of migration. The distribution from shore is variable with whales present both offshore and near shore, although not necessarily in bays. SAGs only start to appear in late winter.

(2) The spring subseasons have in common higher abundance, larger group sizes, a strongly inshore distribution $(<1 \mathrm{~km}$ and inside bays), and lower swimming speeds. This episode signals the start of directionality that alternates between a mean southerly (in early spring) to a northerly bearing in mid-spring, and again significantly south-bound in late spring. Furthermore, neither strong nor weak linearity dominates at any time. Groups of more than three individuals are more common and from early spring, SAGs become a regular feature, especially in bays.

(3) In early summer we find the highest relative abundance, a continuation of large groups occurring farther from shore, and movement at significantly lower speeds. While the north-to-south alternations continue, the onset of the summer feeding season is signaled by random directionality, very low linearity of movement coupled with an increase in milling behavior, and observations of actual feeding and defecations (Table 4, Fig. 7). Groups with individual aerial activity increase, and although low numbers of SAGs are still seen, we believe these to be larger groups with individual surface activity (probably associated with feeding), rather than true SAGs as described in the core nursery areas by Best et al. (2003).

\section{The West Coast as Calving Ground and Nursery Area?}

Overall, the extreme near-shore distribution of right whales found at Saldanha Bay is congruent with the south coast aerial survey results (Best 1990, Elwen and Best $2004 a$ ), as is their strong preference for shallow bays during spring. Locations on the south coast are known areas of concentration for cow-calf pairs presumably due to the favorable conditions they offer, such as shelter from prevailing open ocean swells and wind, and sandy floors with gentle slopes (Elwen and Best 2004a, b, c). In comparison, the west coast is much more exposed to the prevailing westerly swells and winds in winter, which includes the peak calving period (mid-August). There are very few large or sheltered bays available on the coastline north of Table Bay, apart from the stretch between St. Helena Bay and Saldanha Bay, which contains a number of smaller bays offering a variety of physical characteristics favorable to right whales. Critical calving habitats for North Atlantic right whales are known to occur at water depths of $10-20 \mathrm{~m}$ and sea surface temperature (SST) of $13^{\circ} \mathrm{C}-15^{\circ} \mathrm{C}$, with apparent preference for SST $<17^{\circ} \mathrm{C}$ (Keller et al. 2012). In contrast, the South African south coast nursery areas for $E$. australis have SSTs in the $19^{\circ} \mathrm{C}-21^{\circ} \mathrm{C}$ range (Demarcq et al. 2003). The west coast habitat has lower nearshore SSTs of $11^{\circ} \mathrm{C}-17^{\circ} \mathrm{C}$ (within the $200 \mathrm{~m}$ depth contour) due to upwelling associated with the Southern Benguela system (Hutchings et al. 2012) and probably has environmental conditions more similar to the Namibian (Roux et al. 2001) than the South African south coast, with the exception of enclosed bays such as Saldanha, where SST may be considerably higher (see values in Table 4). However, both the west and south coast sites are well within the SST range recorded at other southern right whale wintering grounds, e.g., New Zealand (Greig et al. 1988, Carroll et al. 2014).

Perhaps the most telling indicator of whether the west coast is a nursery area is the presence or absence of cow-calf pairs. During the few past west coast aerial surveys (Best 1990) the sightings mostly consisted of unaccompanied whales (i.e., those with- 
out calves, see Best 2000), in contrast to the south coast where cows and their calves made up more than $50 \%$ of all whales. This agrees with the low numbers of cow-calf pairs we recorded and the confirmation that the smallest calf we saw, although well within the size range of neonates, was born along the south coast at least $10.5 \mathrm{wk}$ earlier; its small size could be attributed to the fact that it was probably a firstborn (Best 1994).

\section{Saldanha Bay and its Environs as a Habitat for Right Whales}

Our findings suggest that despite the availability of shallow water and sheltered bays, these were favored by SAGs rather than cow-calf pairs, and regardless of the prevailing SST, the west coast in general and Saldanha Bay in particular, does not represent an important nursery area for southern right whales. Rather, it has multiple habitat functions. For most of the year the area is utilized mainly by unaccompanied whales transiting the coast or interacting socially in bays and closer to shore, until spring and early summer when the area functions as a feeding ground (Best 2006b). Evidence from Argentina suggests that feeding and nursing are not entirely exclusive, with observations of southern right whales (including cows with calves) feeding on copepod patches during a brief $5 \mathrm{~d}$ period in October 2005 (Hoffmeyer $e t$ al. 2010). However, on the west coast of South Africa the highly productive Southern Benguela upwelling (Hutchings et al. 2012) and high copepod biomass make it a very different habitat from the south coast with its warmer water but no equivalent nearshore food sources (Grémillet et al. 2008). On the west coast the distribution of prey in late spring and summer probably contributes greatly to the observed movement patterns and distribution farther offshore. However, it does not explain the dominance of southbound groups in autumn to mid-winter which suggests a migration from somewhere to the north, rather than from higher latitude feeding grounds to the south.

The historical range of right whales in South African coastal waters in winter is known to have extended to at least $17^{\circ} \mathrm{S}$ off the west coast, and $27^{\circ} \mathrm{S}$ on the east coast (Richards 2009). Seasonal trends in 19th century southern right whale catches between $30^{\circ} \mathrm{W}$ and $80^{\circ} \mathrm{E}$ (based on Townsend's 1935 chart, and presented by Best 1970), show most catches during June and July to have occurred between $20^{\circ} \mathrm{S}$ and $30^{\circ} \mathrm{S}$; that is north of the latitude of Saldanha Bay.

Possibly with the gradual shift (from east to west) in right whale distribution along the south coast of South Africa over the last $40 \mathrm{yr}$, and annual population growth in the region of 7\% (Best 1990, 2000; Best and Scott 1993; Brandão et al. 2010), right whales (including cow-calf pairs) may ultimately begin to re-occupy some of their former range on the west coast (see also Richards 2009). Maternal philopatry has been implicated in the preference shown for certain wintering areas (Best 2000) or the return to former nursery grounds, e.g., New Zealand (Carroll et al. 2014). Ongoing monitoring of right whales is especially important in the light of biological regime shifts and climatic changes that have been recorded in these marine systems over the last few decades (Cury and Shannon 2004, Roualt et al. 2010); such changes are known to affect the distribution of cetaceans (Benson et al. 2002) and other marine predators (Hutchings et al. 2012).

Finally, as South Africa's largest natural port, Saldanha Bay's iron ore railway line and jetty has the capacity to move 93 million tons of material per annum with considerable volumes of associated ship traffic. In the 2011/2012 financial year it handled 528 ships (total gross tonnage of $34,503,749$ ) and total cargo exceeding 58 million 
tons, of which $>90 \%$ were exports. ${ }^{2}$ This implies on average nearly three transits of the mouth of the bay every $24 \mathrm{~h}$ by cargo ships, with an additional unknown number of transits by fishing vessels and other smaller craft. The area has also been designated as an Industrial Development Zone by the South African Government, with a strong emphasis on expanding oil and gas developments along this coast. Right whales, including SAGs and cow-calf pairs, showed no sign of avoiding the mouth of the bay and prescribed shipping lanes (Fig. 7). It is thus important to continue the monitoring of southern right whale numbers and range expansion in the area, especially given the species' potential vulnerability to ship-strikes, as described for its North Atlantic counterpart (Nowacek et al. 2004).

\section{ACKNOWLEDGMENTS}

We declare that we are unaware of any conflicts of interest relating to this work. All research was authorized by annual permits issued to PBB in terms of Regulation 58 of the Marine Living Resources Act, 1998 (Act no. 18 of 1998) administered by the then Department of Environment Affairs and Tourism (South Africa). Specific clearance to conduct such research was not required from the University of Pretoria Ethics Committee prior to 2004. The research received funding from the National Research Foundation (NRF) of South Africa (Grant no. 2047517), the Earthwatch Institute, and PADI Project AWARE UK (Small Grant no. 095). JB was the grateful recipient of postgraduate bursaries from the University of Pretoria and NRF, a Grant-in-Aid from the Society for Marine Mammalogy, and the Charles Astley Maberly Memorial bursary from the Wildlife Society of South Africa. The Mazda Wildlife Fund is thanked for the provision of a field vehicle, and SASOL, for the donation of two four-stroke boat engines. We are extremely indebted to the South African Navy for granting access to the shore-based lookouts, and for a boat mooring. Prof J. Malan and Col. N. Slabber of the South African Military Academy are thanked for the provision of logistical help, including access to computer facilities and accommodation. Data collection would have been impossible without the support of Meredith Thornton, and assistance of 13 Earthwatch and nearly 100 other local and international volunteers, to all of whom we owe a big debt of gratitude. Particular thanks are due to Maria Sabo, Erich Koch, Simon Elwen, Shaun Dillon, Theoni Photopoulou, Laura Beskers, Isabelle Fontaine, Pauline Delos, André du Randt, Jenny Brash, and Nick van Barneveld who all volunteered for longer than four weeks. The South African Naval Hydrographic Office kindly supplied tidal height measurements and the South African Weather Service climate data for Cape Columbine. We thank two anonymous referees for comments that helped to greatly improve earlier submissions.

\section{Literature Cited}

Barendse, J., P. B. Best, M. Thornton, C. Pomilla, I. Carvalho and H. C. Rosenbaum. 2010. Migration redefined? Seasonality, movements and group composition of humpback whales Megaptera novaeangliae off the west coast of South Africa. African Journal of Marine Science 32:1-22.

Barendse, J., P. B. Best, M. Thornton, et al. 2011. Transit station or destination? Attendance patterns, movements, and abundance estimate of humpback whales off west South Africa from photographic and genotypic matching. African Journal of Marine Science 33:353373.

${ }^{2}$ http://ports.co.za/saldanha-bay.php. Accessed in December 2013. 
Benson, S. R., D. A. Croll, B. B. Marinovic, F. P. Chavez and J. T. Harvey. 2002. Changes in the cetacean assemblage of a coastal upwelling ecosystem during El Ninõ 1997-98 and La Ninã 1999. Progress in Oceanography 54:279-291.

Best, P. B. 1970. Exploitation and recovery of right whales Eubalaena australis off the Cape Province. Investigational Report, Division of Sea Fisheries, Republic of South Africa 80:1-20.

Best, P. B. 1990. Trends in the inshore right whale population off South Africa, 1969-1987. Marine Mammal Science 6:93-108.

Best, P. B. 1994. Seasonality of reproduction and the length of gestation in southern right whales Eubalaena australis. Journal of Zoology, London 232:175-189.

Best, P. B. 2000. Coastal distribution, movements and site fidelity of right whales Eubalaena australis off South Africa, 1969-1998. South African Journal of Marine Science 22:4355 .

Best, P. B. 2006a. The presence of right whales in summer on the west coast of South Africa: The evidence from historical records. African Journal of Marine Science 28:159-166.

Best, P. B. 2006b. Not all the whales leave in summer! Village Life 19:14-18.

Best, P. B., and B. Mate. 2007. Sighting history and observations of southern right whales following satellite tagging off South Africa. Journal of Cetacean Research and Management 9:111-114.

Best, P. B., and G. J. B. Ross. 1986. Catches of right whales from shore-based establishments in Southern Africa, 1792-1975. Report of the International Whaling Commission (Special Issue 10):275-289.

Best, P. B., and H. A. Scott. 1993. The distribution, seasonality and trends in abundance of southern right whales Eubalaena australis off De Hoop Nature Reserve, South Africa. South African Journal of Marine Science 13:175-186.

Best, P. B., R. Payne, V. Rowntree, J. T. Palazzo and M. C. Both. 1993. Long range movements of South Atlantic right whales Eubalaena australis. Marine Mammal Science 9:227-234.

Best, P. B., K. Sekiguchi and K. P. Findlay. 1995. A suspended migration of humpback whales Megaptera novaeangliae on the west coast of South Africa. Marine Ecology Progress Series 118:1-12.

Best, P. B., A. Brandão and D. S. Butterworth. 2001. Demographic parameters of southern right whales off South Africa. Journal of Cetacean Research and Management (Special Issue) 2:161-170.

Best, P. B., C. M. Schaeff, D. Reeb and P. J. Palsbøll. 2003. Composition and possible function of social groupings of southern right whales in South African waters. Behaviour 140:1469-1494.

Brandão, A., P. B. Best and D. Butterworth. 2010. Estimates of demographic parameters for southern right whales off South Africa from survey data 1979 to 2006. Unpublished report (SC/62/BRG30) presented to the Scientific Committee of the International Whaling Commission, Cambridge, U.K.

Burnell, S. R., and M. M. Bryden. 1997. Coastal residence periods and reproductive timing in southern right whales, Eubalaena australis. Journal of Zoology, London 241:613-621.

Carroll, E., N. Patenaude, A. Alexander, et al. 2011. Population structure and individual movement of southern right whales around New Zealand and Australia. Marine Ecology Progress Series 432:25-268.

Carroll, E. L., W. J. Rayment, A. M. Alexander, et al. 2014. Reestablishment of former wintering grounds by New Zealand southern right whales. Marine Mammal Science 30:206-220.

Cury, P., and L. Shannon. 2004. Regime shifts in upwelling ecosystems: Observed changes and possible mechanisms in the northern and southern Benguela. Progress in Oceanography 60:223-243. 
Demarcq, H., R. G. Barlow and F. A. Shillington. 2003. Climatology and variability of sea surface temperature and surface chlorophyll in the Benguela and Agulhas ecosystems as observed by satellite imagery. African Journal of Marine Science 25:363-372.

Elwen, S. H., and P. B. Best. 2004a. Environmental factors influencing the distribution of southern right whales (Eubalaena australis) on the south coast of South Africa I: Broad scale patterns. Marine Mammal Science 20:567-582.

Elwen, S. H., and P. B. Best. 2004b. Environmental factors influencing the distribution of southern right whales (Eubalaena australis) on the south coast of South Africa II: Within bay distribution. Marine Mammal Science 20:583-601.

Elwen, S. H., and P. B. Best. 2004c. Female southern right whales Eubalaena australis: Are there reproductive benefits associated with their coastal distribution off South Africa? Marine Ecology Progress Series 269:289-295.

Gailey, G., and J. G. Ortega-Ortiz. 2000. Pythagoras: Theodolite cetacean tracking. Marine Mammal Research Program, Texas A\&M University at Galveston, Galveston, TX.

Gailey, G., and J. G. Ortega-Ortiz. 2002. A note on a computer-based system for theodolite tracking of cetaceans. Journal of Cetacean Research and Management 4:213-218.

Greig, M. J., N. M. Ridgway and B. S. Shakespeare. 1988. Sea surface temperature variations at coastal sites around New Zealand. New Zealand Journal of Marine and Freshwater Research 22:391-400.

Grémillet, D., S. Lewis, L. Drapeau, et al. 2008. Spatial match-mismatch in the Benguela upwelling zone: Should we expect chlorophyll and sea surface temperature to predict marine predator distributions? Journal of Applied Ecology 45:610-621.

Hoffmeyer, M. S., M. S. Lindner, A. Carribero, et al. 2010. Planktonic food and foraging of Eubalaena australis, on Peninsula Valdés (Argentina) nursery ground. Revista de Biología Marina y Oceanografía 45:131-139.

Hutchings, L., A. Jarre, T. Lamont, et al. 2012. St Helena Bay (southern Benguela) then and now: Muted climate signals, large human impact. African Journal of Marine Science 34:559-583.

Keller, C. A., L. Garrison, R. Baumstark, L. I. Ward-Geiger and E. Hines. 2012. Application of a habitat model to define calving habitat of the North Atlantic right whale in the southeastern United States. Endangered Species Research 18:73-87.

Mate, B. R., P. B. Best, B. A. Lagerquist and M. H. Winsor. 2011. Coastal, offshore, and migratory movements of South African right whales revealed by satellite telemetry. Marine Mammal Science 27:455-476.

Nowacek, D. P., M. P. Johnson and P. L. Tyack. 2004. North Atlantic right whales (Eubalaena glacialis) ignore ships but respond to alerting stimuli. Proceedings of the Royal Society, London B 271:227-231.

Pirzl, R., N. J. Patenaude, S. Burnell and J. Bannister. 2009. Movements of southern right whales (Eubalaena australis) between Australian and subantarctic New Zealand populations. Marine Mammal Science 25:455-461.

Richards, R. 2009. Past and present distributions of southern right whales (Eubalaena australis). New Zealand Journal of Zoology 36:447-459.

Richards, R., and T. Du Pasquier. 1989. Bay whaling off Southern Africa, c. 1785-1805. South African Journal of Marine Science 8:231-250.

Rowntree, V. J., R. S. Payne and D. M. Shell. 2001. Changing patterns of habitat use by southern right whales (Eubalaena australis) on their nursery ground at Península Valdés, Argentina, and in their long-range movements. Journal of Cetacean Research and Management (Special Issue) 2:133-143.

Rouault, M., B. Pohl and P. Penven. 2010. Coastal oceanic climate change and variability from 1982 to 2009 around South Africa. African Journal of Marine Science 32:237-246.

Roux, J.-P., P. B. Best and P. E. Stander. 2001. Sightings of southern right whales (Eubalaena australis) in Namibian waters, 1971-1999. Journal of Cetacean Research and Management (Special Issue) 2:181-185. 
Roux, J. P., R. Braby and P. B. Best. 2011. Southern right whales off Namibia and their relationship with those off South Africa. Unpublished paper SC/S11/RW16 submitted to International Whaling Commission Workshop on the Assessment of Southern right whales, September 2011, Buenos Aires, Argentina.

Thompson, W. W. 1913. The sea fisheries of the Cape Colony. Chapter V. The whale and seal fisheries. T. Maskew Miller, Cape Town and Pretoria, South Africa.

Tormosov, D. D., Y. A. Mikhaliev, P. B. Best, V. A. Zemsky, K. Sekiguchi and R. L. Brownell, Jr. 1998. Soviet catches of southern right whales Eubalaena australis, 1951-1971. Biological data and conservation implications. Biological Conservation 86:185-197.

Townsend, C. H. 1935. The distribution of certain whales as shown by logbook records of American whaleships. Zoologica, N.Y. 19:1-50.

Zar, J. H. 1996. Biostatistical analysis. Prentice Hall, Upper Saddle River, NJ. 